\title{
ESO 法とグランドストラクチャ法を用いた骨組構造物の位相最適化 TOPOLOGY OPTIMIZATION OF FRAME STRUCTURES USING ESO METHOD AND GROUND STRUCTURE METHOD
}

\author{
高坂 憲治*，松本慎也**，藤井大地*** \\ Kenji KOSAKA, Shinya MATSUMOTO and Daiji FUJII
}

\begin{abstract}
In this paper, a simple method for topology optimization of frame structures is proposed. In this method, ESO (Evolutionary Structural Optimization) method is applied to ground structure method. An exact optimal solution may not be obtained by ESO method because it is a heuristic method. However, the approximate solution useful for structural design can be obtained by this method. In the proposed method, the ground structure is generated by connecting all nodes by beam elements (but it is possible to limit the maximum length of the elements, and it is also possible to remove the unnecessary elements), and in the optimization process, the elements with the lowest strain energy are deleted based on ESO method. In order to demonstrate the effectiveness of the proposed method, in several numerical examples, the solutions obtained by the proposed method are compared with the solutions obtained by the density approach method (mathematical programming).
\end{abstract}

Keywords: Topology optimization, ESO method, Ground structure method, Frame structure, Computational Morphogenesis 位相最適化，ESO 法，グランドストラクチャ法，骨組構造，構造形態創生

\section{1. はじめに}

近年，解析技術や生産・製造技術等の発達により，様々な形態の 建築物が造られるようになってきている. また, 3D プリンタの普及 により，より軽量で剛性の高い構造形態を創生する技術の必要性が 高まっている．位相最適化手法は，このようなニーズに応えうる形 態創生手法の一つである.

このような位相最適化手法には，連続体を対象とするものと骨組 構造を対象とするものがある. 骨組構造を対象とする方法は, 一般 にグランドストラクチャ法 ${ }^{1-3)}$ と呼ばれており, 設計領域に適当な節 点を配置し，節点間を可能な限りの線要素で結んだグランドストラ クチャに対して, 各線要素の材料密度（または断面積）を最適化す ることで最適位相を求めるものである，特に，建築構造は，骨組構 造として設計される場合が多いため, 骨組構造の位相最適化は, 建 築構造の形態創生や耐震ブレース・制震ブレースの最適配置問題な ど幅広い応用分野が考えられる.

建築分野のグランドストラクチャ法による位相最適化の研究とし ては, トラス構造（ピン接合）を対象とした河村, 大森の研究 ${ }^{4)}$, 高田, 松岡の研究 ${ }^{5}$, 骨組構造 (剛接合) を対象とした藤井らの研 究 ${ }^{6-8)}$, 河村, 大森の研究 ${ }^{9}$ などが挙げられる. 河村, 大森の研究で は，最適化手法として GA（Genetic Algorithm）が用いられており， 高田, 松岡の研究では線形計画法が, 藤井らの研究では非線形計画
法が用いられている。また，これまでの研究では，骨組の各要素の 材料密度（または断面積）を最適化することで位相を求めるため, 解として得られた位相の各要素の太さは一般に異なっている.特に, 高田, 松岡の方法 ${ }^{5)}$ では, 断面積の上限が制約されていないため, 部材太さが大きく異なる場合も見られる。また，藤井ら方法 ${ }^{6-8)}$ は， 連続体の SIMP（Solid Isotropic Material with Penalization）法と同様に 材料密度の $0 / 1$ 問題としても解けるため, 原理的には部材太さを均 一に近づけることも可能だが，多くの場合中間密度（細い部材）が 残る。一方，河村，大森 ${ }^{4,99}$ の方法で用いられている GA では，この ような問題は容易に解決できるが，部材数が多くなると計算効率が 悪く, 計算負荷の大きい動的問題や非線形問題への応用が難しい.

一方，連続体の位相最適化では，中間的な材料密度を完全に除く 方法として，Xie，Steven らによって提案された ESO 法 ${ }^{10}$ および BESO (Bi-directional Evolutionary Structural Optimization) 法 ${ }^{11}$ がある. 本方法は，最適解への収束の保証が無い発見的手法ではあるが，剛 性最大化問題では, 数理計画法にもとづくSIMP 法に比較しても遜 色の無い方法であることが示されている ${ }^{12)}$ ．また，本方法は，骨組 問題（グランドストラクチャ法）にも応用されている ${ }^{13)}$.

そこで本研究では, 文献 13)の方法に着目し, この方法を応用寸 ることで, 建築骨組の形態創生, あるいは耐震ブレースや制震ブレ ースの最適配置問題に利用できないかを検討する，ただし，本研究
* 近畿大学大学院 大学院生

** 近畿大学工学部 准教授 $\cdot$ 博士 (工学

*** 近畿大学工学部 教授. 博士 (工学 $)$
Grad. Stud., Graduate School of Systems Engineering, Kinki University

Assoc. Prof., Faculty of Engineering, Kinki University, Dr.Eng.

Prof., Faculty of Engineering, Kinki University, Dr.Eng. 
で提案する方法は, 既往の研究のように部材断面積（材料密度）を 連続的（段階的）に変化させるのではなく，ひずみエネルギー密度 の小さい部材 (要素) を順に除いていく単純な方法で, 問題によっ ては, 文献 14 に指摘されているように最適解を見逃寸可能性もある. しかしながら, 建築構造設計を考える場合, 最適解が必ずしも実用 的な解とはならないため, 最適解に近い優良解（初期設計を改善す る解)が得られれば, 実務上は十分有効に活用できると考えられる.

以下本論文 2 章では, 提案手法の有効性を確かめるために比較に 用いる文献 8,15 に示すグランドストラクチャ法の概要を示す. 3 章 では, 提案手法である ESO 法をグランドストラクチャ法に適用する 方法を示寸. 4 章では, 提案手法と従来法との比較により, 提案手 法の有効性を検証する．5章では以上のまとめを述べる．

\section{2. 比較に用いるグランドストラクチャ法}

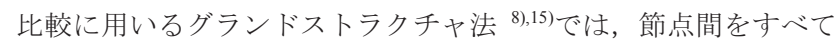
の可能な線要素で連結したグランドストラクチャに対して, $i$ 番目 要素の剛性マトリクス $\mathbf{k}_{i}$ を要素密度 $\rho_{i}$ を用いて次式のように表す.

$$
\mathbf{k}_{i}=\rho_{i}^{p} \mathbf{k}_{i}^{0} \quad 0<\rho_{i} \leq 1
$$

ここに, $\mathbf{k}_{i}^{0}$ は初期の要素剛性マトリクス, $p$ はべキ乗の係数であり, 1 より大きい值を与えることにより, $0<\rho_{i}<1$ の場合, 実際の密度 より $\mathbf{k}_{i}$ が小さく評価される.ただし, 文献 8,15 では, 密度の上限は 制約していないが，ここでは上限を 1 に制約している.

位相最適化問題は, 設計変数 $\boldsymbol{\rho}=\left\{\rho_{1}, \rho_{2}, \cdots, \rho_{i}, \cdots, \rho_{N}\right\}$ に対 して, 質量制約下でコンプライアンスを最小化する次の問題として 定式化される。

$$
\begin{aligned}
& \min C(\boldsymbol{\rho})=\mathbf{d}^{T} \mathbf{K d}=\mathbf{d}^{T} \mathbf{f} \\
& \text { subject to } m(\boldsymbol{\rho})=\sum_{i=1}^{N} \rho_{i} A_{i} l_{i} \leq \bar{m}, \quad 0<\rho_{i} \leq 1 \quad(i=1, \cdots, N)
\end{aligned}
$$

ここに, $C$ はコンプライアンス $, \mathbf{d}, \mathbf{f}$ は節点変位ベクトルと節点外 カベクトル， $\mathbf{K}$ は全体剛性マトリクス， $m$ は質量， $N$ は要素数, $A_{i}, l_{i}$ は $i$ 番目要素の断面積と長さ, $\bar{m}$ は質量の制約值を表す.

本論文では，(2)式の最適化問題をCONLIN 法 ${ }^{8), 15)}$ を用いて解く. ただし，CONLIN 法の改修計算回数は 40 としている。しかしなが ら, 本問題は, 初期值依存性の高い多峰性問題であるため, 1 回の 最適化計算では大域的最適解に収束しない場合がある. そこで, 文 献 8,15 では最適化計算で得られた解を再度初期值として同じ最適 化計算を繰り返す方法を用いており, 本論文でもこの方法を採用す る. なお，この最適化計算の繰り返し回数を再計算回数と呼ぶ.ま た, 文献 8,15 では, (1)式のべき乗係数 $p$ を再計算にしたがって 1 から徐々に増加させる方法を用いているが, ここでは $p$ は初期に与 えた值で固定する.

\section{ESO 法を用いたグランドストラクチャ法}

ここでは, 初期の ESO 法 ${ }^{10)}$ の考え方にもとづき, 非常にシンプル な計算アルゴリズムを提案する.

まず，グランドストラクチャの作成法は従来どおりである. 文献 15 には, Excel によるプリプロセスでグランドストラクチャを自動 生成するソフトが提供されているので参照されたい. 本ソフトでは, 生成される要素長さの上限を設定でき, また, 設計対象要素と非設
計対象要素を区別できるようになっている.

本方法では, 以上のグランドストラクチャに対して以下の計算ア ルゴリズムを適用する.

(1) グランドストラクチャの静的弾性解析を行い, 各設計対象要素 のひずみエネルギー密度を計算する。なお，(1)，(2)式の表記 を用いれば $i$ 番目要素のひずみエネルギー密度 $V_{i}$ は次式によ り計算される。

$$
V_{i}=(1 / 2) \mathbf{d}_{i}^{e T}\left(\rho_{i} \mathbf{k}_{i}^{0}\right) \mathbf{d}_{i}^{e} /\left(A_{i} l_{i}\right)
$$

ただし, $\mathbf{d}_{i}^{e}$ は $i$ 番目要素の節点変位である. また, 要素密度 $\rho_{i}$ は, 残存している要素は 1 とし, 除去要素は $1 / 10^{3}$ とする。 な お, 除去要素の密度を 0 としないのは, 不安定構造になった時 の連立方程式の特異性を避けるためである。

(2) 設計対象要素（残存要素）の要素番号をひずみエネルギー密度 の小さい順に並べる。

(3) 最もひずみエネルギー密度の小さい要素番号の要素をグラン ドストラクチャから除去する。なお，同じ最小ひずみエネルギ 一密度の要素が複数ある場合は, 複数除去する。(これは対称 性を有する構造の対称性を保つための処置でもある.)

(4) すべての設計対象要素が無くなるまで(1)〜(3)を繰り返す.

(5) 汎用可視化ソフトを用いて，すべての除去ステップを参照し， 優良解を選定寸る.

以上のプロセスを図 1 の簡単なトラスの例題で示寸. 図 1 には, 解析モデルとすべての除去ステップを汎用可視化ソフトで表示した 結果を示している (上記プロセス(5)). 図に示すように, 各ステップ でひずみエネルギー密度が最小となる要素が 1 要素ずつ除去されて いることがわかる. 図中, Step2 と Step4 は不安定構造となっている が，除去要素の密度を $1 / 10^{3}$ としているため解が得られている.

以上のように，本手法は，非常に単純であり，また，中間密度が 無いため，解の選択も容易であることがわかる.

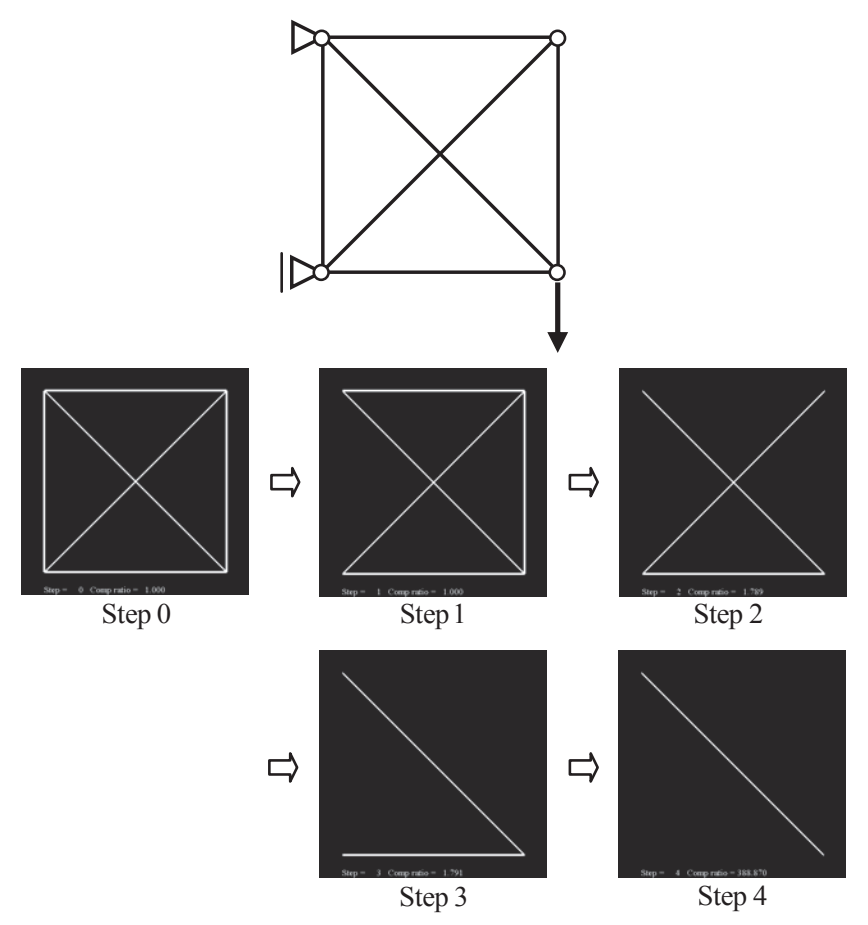

図 1 トラスの解析モデルと解析プロセス 


\section{4. 解析例}

ここでは，3 章で提案した単純な手法（提案手法）の有効性を, 2 章に示寸数理計画法にもとづく手法（以下比較手法と呼ぶ）との 比較により検証する。

\subsection{9 節点トラス構造の位相最適化}

図 2 は, 基本的なトラス構造のグランドストラクチャを示す. 部 材断面積はすべて等しく，接合部および支点はピン接合である.

図 3 は, Case A について 3 章に示寸提案手法の全ステップの解析 結果を示している. 図中には, 各ステップのコンプライアンス比 $C / C^{0}$ （ $C^{0}$ は 0 ステップのコンプライアンス）も示している. 図 3 において, Step 3, 6, 7 は不安定構造であるが, 除去要素が微小密度 $\left(1 / 10^{3}\right)$ を有しているため解が得られている。また，Step 3, 4 は， 剛性に寄与しない要素を除くと Step 5 と同じになる. 図 4 は, 2 章 に示す比較手法の解析結果（Case A）を示す。ただし，(1)式のべき 乗数 $p$ と質量制約 $\bar{m} / m^{0} \quad\left(m^{0}\right.$ は初期構造の質量）は, 図に示寸とお りである. 再計算回数は 30 としている. 図 3 と図 4 を比較すると, 図 4 の比較手法の最適位相は提案手法の Step 5 で得られていること がわかる。

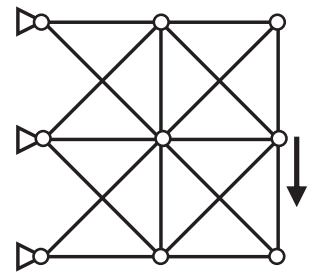

Case A

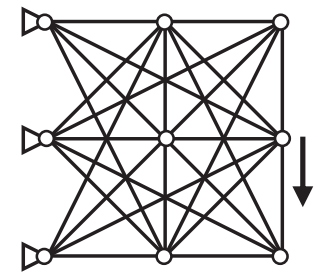

Case B

図 2 解析例 1 (9 節点トラス)

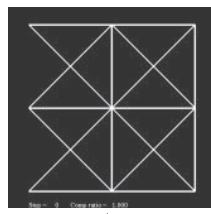

Step $0 \quad C / C^{0}=1.000$
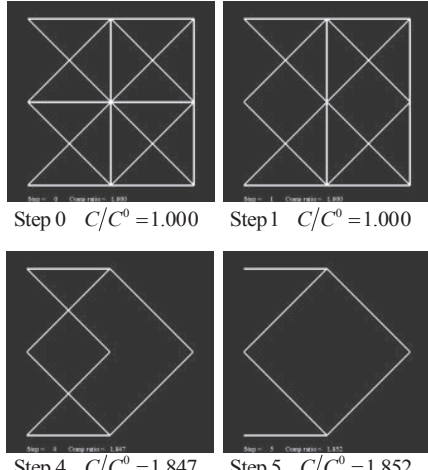

Step $1 \quad C / C^{0}=1.000$
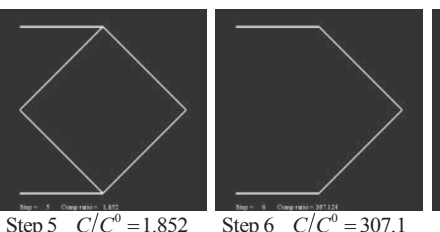

Step $6 \quad C / C^{0}=307.1$
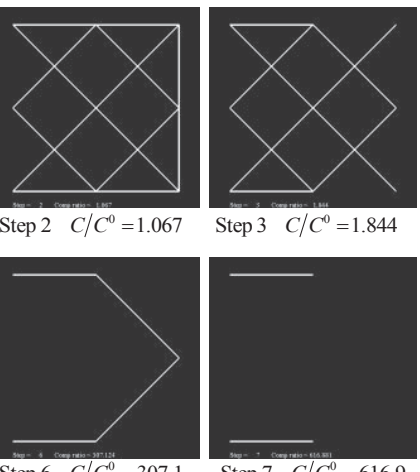

図 3 解析例 1 （Case A）の提案手法による解析結果

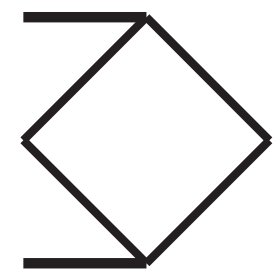

$p=2 \quad \bar{m} / m^{0}=0.3$

図 4 解析例 1 (Case A) の比較手法による解析結果
図 5 と図 6 は, Case B について, 提案手法の全ステップの解析結 果と比較手法の解析結果を示している。ただし，比較手法の質量制 約とべき乗数 $p$ は図に示すとおりで, 再計算回数は 1 回としている. 図より，この場合も，比較手法の $\bar{m} / m^{0}=0.3, \bar{m} / m^{0}=0.1$ の解は提案 手法の Step 9, Step11 の解と一致することがわかる。
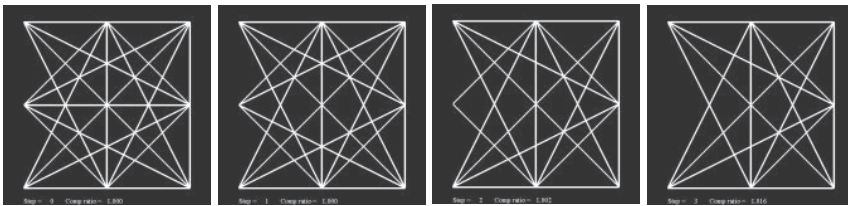

Step $0 \quad C / C^{0}=1.000$

Step $1 \quad C / C^{0}=1.000$

Step $2 C / C^{0}=1.002$

Step $3 C / C^{0}=1.016$
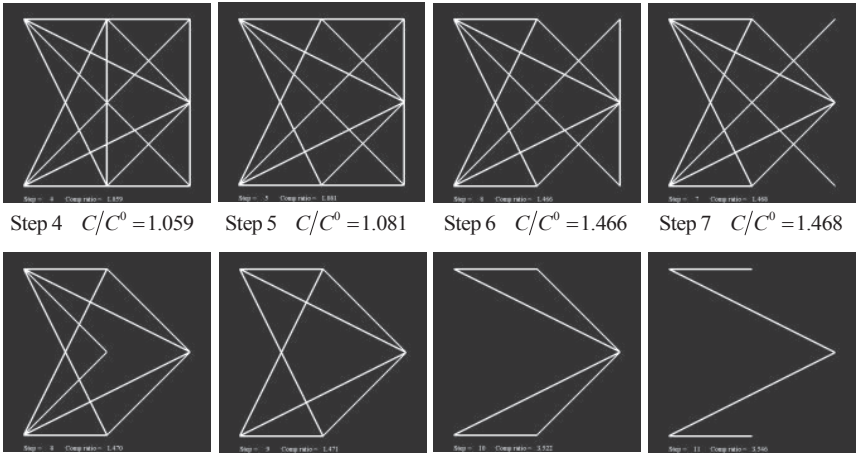

Step $5 C / C^{0}=1.081$
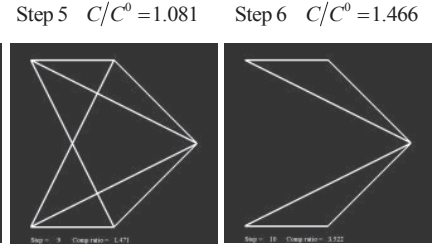

Step $7 \quad C / C^{0}=1.468$

Step $8 \quad C / C^{0}=1.470$

Step $9 \quad C / C^{0}=1.471$

Step $10 \quad C / C^{0}=3.522$
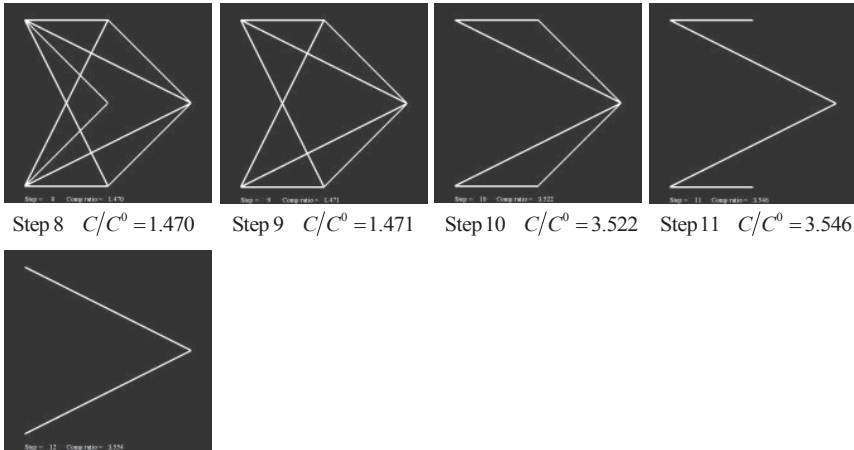

Step $11 C / C^{0}=3.554$

図 5 解析例 1 (Case B) の提案手法による解析結果

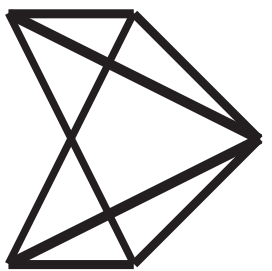

$p=2 \quad \bar{m} / m^{0}=0.3$

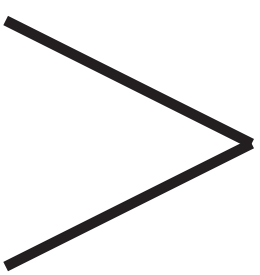

$p=2 \quad \bar{m} / m^{0}=0.1$
図 6 解析例 1 (Case B) の比較手法による解析結果

\subsection{5 節点トラス構造の位相最適化}

次に, 図 7 は, 15 節点のトラス構造のグランドストラクチャを示 す.ただし, Case A と Case B では, 支持点と荷重点の位置が異なる. 図 8, 図 9 は, 提案手法の解と比較手法の解を比較したものである. ただし，比較手法の質量制約は $\bar{m} / m^{0}=0.1$, 再計算回数は 100 とし ている。これらの図より, Case A は似通った位相, Case B は一致し た位相が得られていることがわかる．ただし，コンプライアンス值 の比較では, 比較手法の結果は部材太さが異なるため, 得られた解 の部材断面積をすべて均一にして再計算したものと比較している. その結果, 図中に示寸ように比較手法の解と提案手法の解のコンプ ライアンス比は, Case A では 0.992, Case B では 1.000 となった。し たがって, Case A では, 提案手法の解の剛性が比較手法の解の剛性 に比較してやや小さいことがわかる. 
以上の結果より, トラス問題では, 図 7 の Case A を除いて, 提案 手法により比較手法の最適位相と一致した解が得られることがわか った。なお, 図 7 の Case A については, 部材太さの不均一性が影響 しているのではないかと考え, 試しに，3 章に示す方法で, 最小ひ ずみエネルギー密度の要素をすぐに除去するのではなく, 要素密度 を $1 \rightarrow 0.5 \rightarrow 1 / 10^{3}$ と, 2 段階で除去する方法で再度解析を行ってみ た。 その結果, 図 10 に示寸ように, 鉛直部材のみ密度 0.5 となる位 相が得られ, 部材太さを均一にすると, 比較手法の解のコンプライ アンスよりも小さくなった。したがって, より最適な位相を得るた めには，要素密度を段階的に小さくする方法も考えられるが，その 分, 解析ステップ数も増加し, また, 中間密度が残ることにより複 雑な位相となる場合もあるため, 本論文では採用しない.

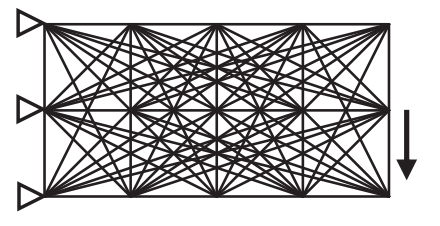

Case A

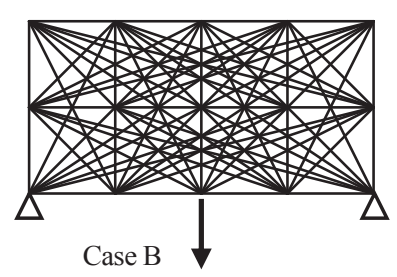

図 7 解析例 2 (トラス)

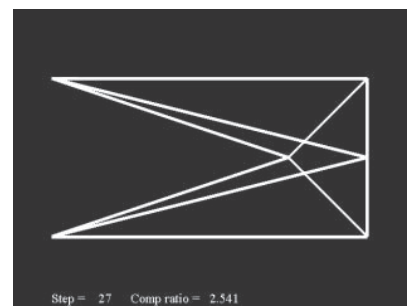

提案手法 Step $27 \quad C / C^{0}=2.541$

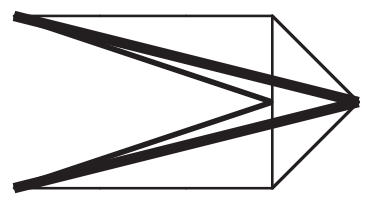

比較手法 $p=2$ $C^{O p t}($ 比較 $) / C^{27}$ (提案 $)=0.992$

図 8 解析例 2（Case A) の解析結果の比較

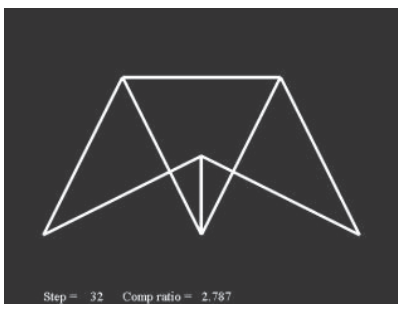

提案手法 Step $32 \quad C / C^{0}=2.787$

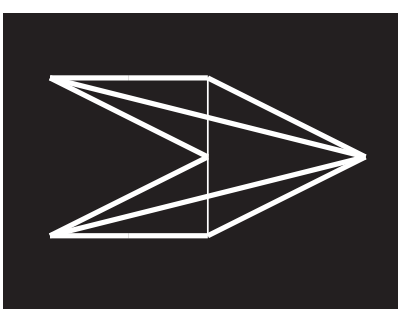

提案手法 Step $67 \quad C / C^{0}=2.242$ $C=66.25$ (均一密度 $C=65.00$ )

図 10 要素密度を 2 段階に変化させた場合の解析結果の比較
4.3 剛接骨組構造の位相最適化

図 11 は節点数 35 の剛接骨組構造の解析モデルとそのグランドス トラクチャを示したものである。部材断面積は均一とし，ヤング係 数は $206 \mathrm{GPa}$, 荷重は $1 \mathrm{kN} / \mathrm{cm}$ の鉛直等分布荷重と $0.2 \mathrm{kN} / \mathrm{cm}$ の水平 等分布荷重を一番上の梁（水平材）に加えている。ただし，荷重が 加わる梁の要素密度は固定（非設計対象要素）とし，それ以外の全 部材を設計対象要素とする.なお, 鉛直荷重による解析と水平荷重 による解析は別々に行っている（1 ステップ 2 回の解析）.
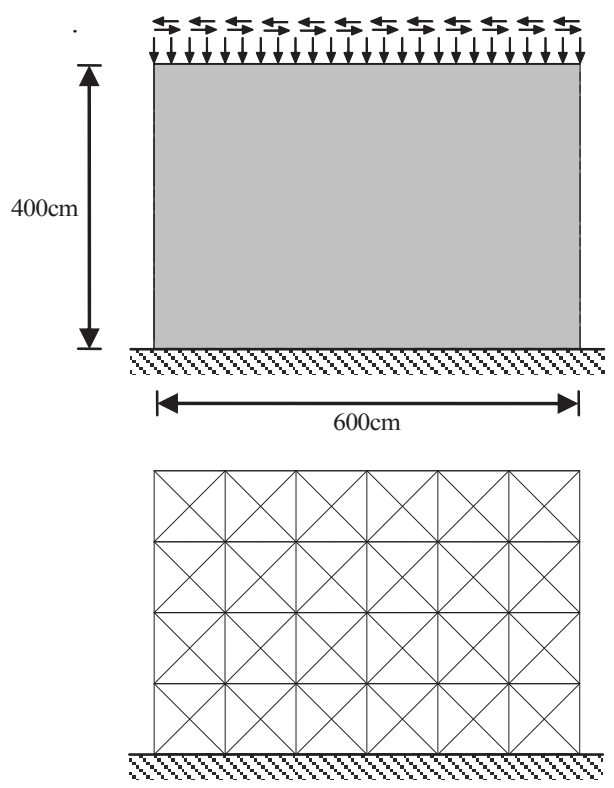

図 11 解析例 3 の解析モデルとグランドストラクチャ

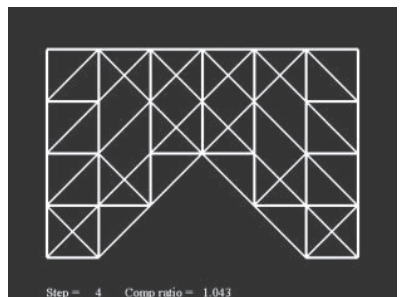

Step $4 \quad C / C^{0}=1.043$

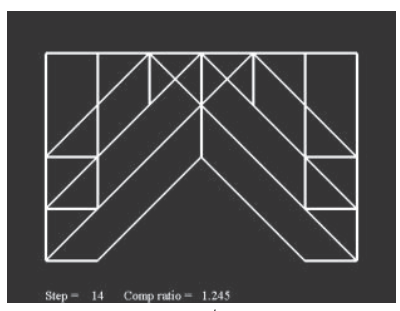

Step $14 C / C^{0}=1.245$

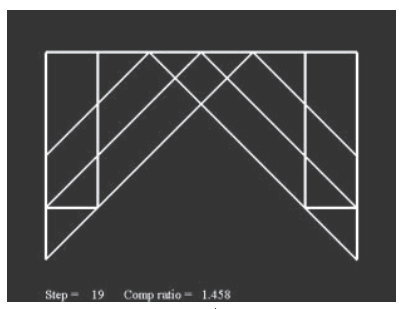

Step $19 C / C^{0}=1.458$

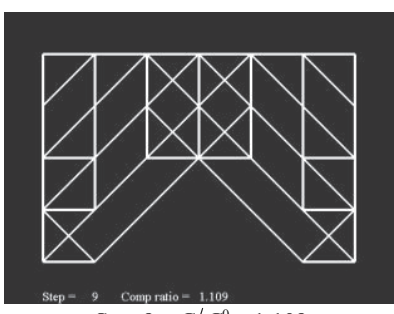

Step $9 C / C^{0}=1.109$

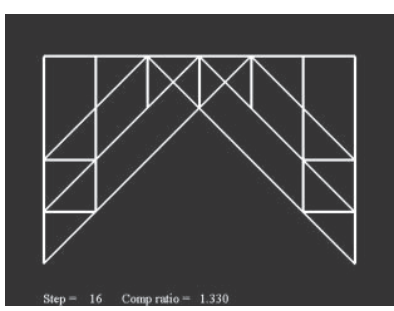

Step $16 C / C^{0}=1.330$

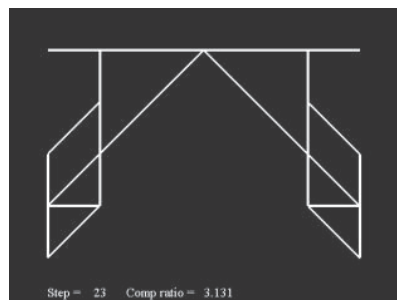

Step $23 C / C^{0}=3.131$
図 12 解析例 3 の提案手法による解析結果 


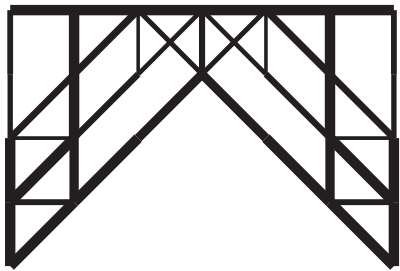

$p=1 \quad \bar{m} / m^{0}=0.3$

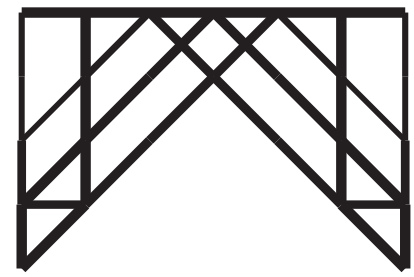

図 13 解析例 3 の比較手法による解析結果

図 12 は, 提案手法の解の中から適当に抽出したステップの解を示 している. また, 図 13 は, 比較手法によって得られた解を示してい る.ただし, 質量制約 $\bar{m} / m^{0}$ およびべき乗数 $p$ は図に示すとおりで あり, 再計算回数は 10 としている. 図 12 と図 13 を比較すると, 比 較手法の $p=1$ の解は, 提案手法の Step 16 の解と一致しており, $p=2$ の解は, Step19 の解と一致していることがわかる.

したがって, 提案手法では, 剛接骨組構造においても, 比較手法 と同じ最適位相が得られることがわかる。ただし，比較手法では， 質量制約やペナルティに用いるべき乗数等の計算条件によって様々 な解が得られるため, 提案手法と比較手法の解が一致するのは, あ る特定の計算条件の解であることに注意が必要である.

\section{4 骨組構造の形態創生}

図 14 は, ビルのファサードの形態創生解析モデルとそのグランド

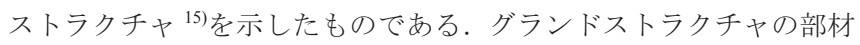
はすべて $10 \mathrm{~cm} \times 10 \mathrm{~cm}$ の中実断面とし, 床梁のヤング係数は鋼材を 想定し $206 \mathrm{GPa}$, 柱および斜材のヤング係数は鉄筋コンクリートを想 定し $20.6 \mathrm{GPa}$ とし, 荷重は $1 \mathrm{kN} / \mathrm{cm}$ の鉛直等分布荷重と $0.2 \mathrm{kN} / \mathrm{cm}$ の 水平等分布荷重を床梁に加え, 床梁は非設計対象要素としている.

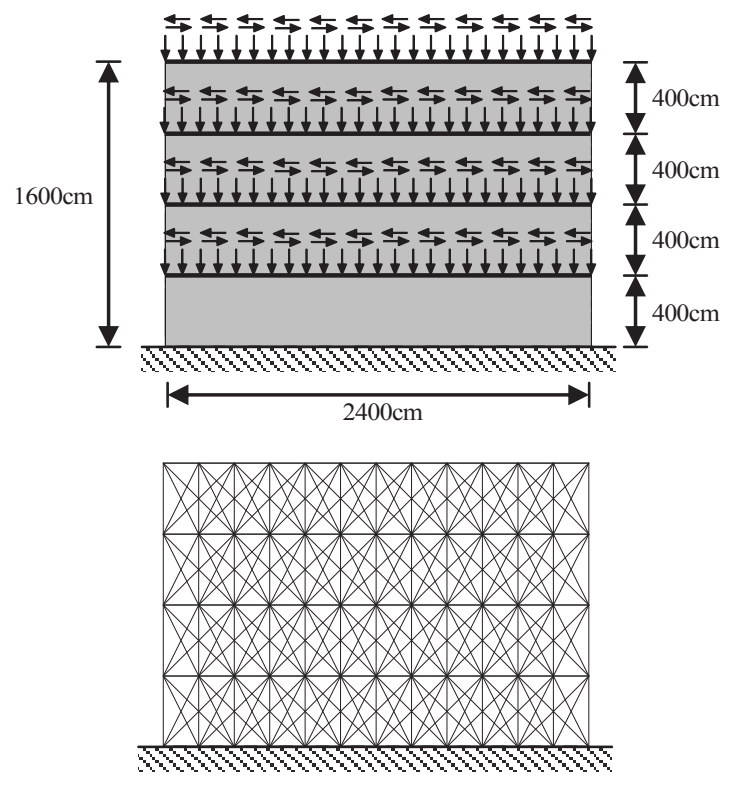

図 14 解析例 4 の解析モデルとグランドストラクチャ

図 15 は, 提案手法の解の中から適当に抽出したステップの解を示 している. 図16 は, 比較手法によって得られた解を示している. た だし, 比較手法の質量制約およびべき乗数は図に示すとおりであり,
再計算回数は 30 としている. 図 15 と図 16 を比較すると, 比較手法 の $\bar{m} / m^{0}=0.2$ の解は, 提案手法の Step 103 あたりの解が類似してお り, $\bar{m} / m^{0}=0.1$ の解は, Step116あたりの解が類似していることがわ かる. しかしながら, ファサードデザインを考える場合, 提案手法 の Step 123, Step128 のような解も設計のヒントを与えると思われる したがって, このようなシンプルな形態まで求められるのは提案手 法の利点と言える。 また，比較手法では中間密度にペナルティを与 えても最適位相の部材太さに違いが見られるのに対して, 提案手法 では部材太さが変わらない位相を求められるところも利点である。

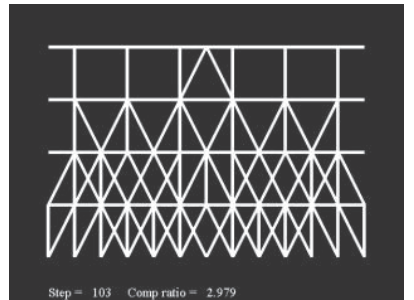

Step $103 C / C^{0}=2.979$

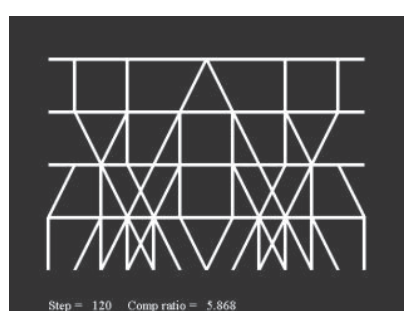

Step $120 \quad C / C^{0}=5.868$

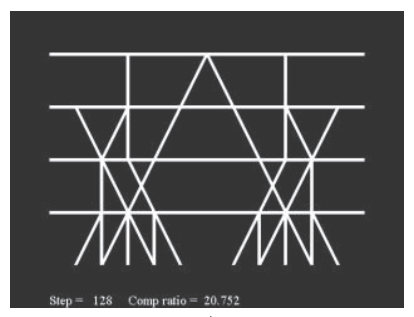

Step $128 C / C^{0}=20.752$

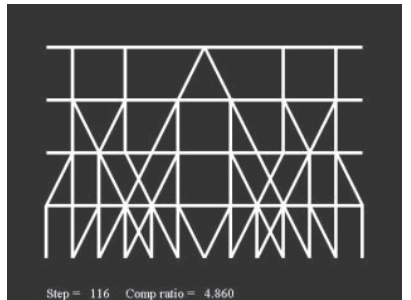

Step $116 C / C^{0}=4.860$

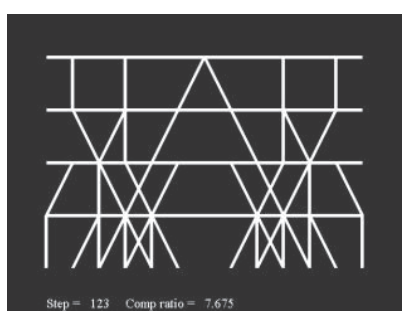

Step $123 C / C^{0}=7.675$

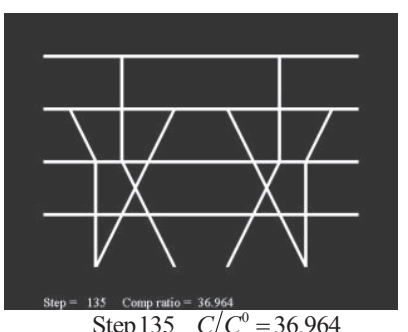

Step $135 C / C^{0}=36.964$
図 15 解析例 4 の提案手法による解析結果

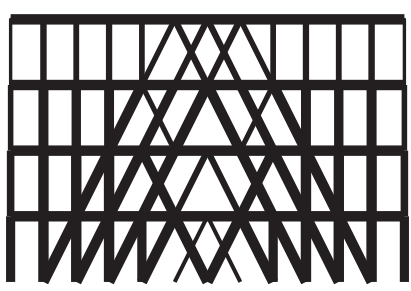

$p=2 \quad \bar{m} / m^{0}=0.2$

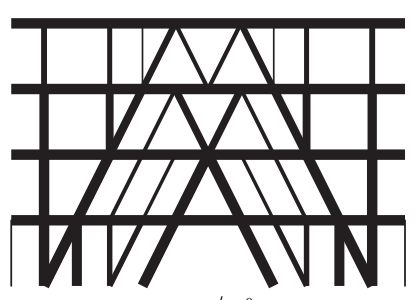

$p=2 \quad \bar{m} / m^{0}=0.1$
図 16 解析例 4 の比較手法による解析結果

図 17 は, 提案手法の Step 123 から考えたファサードデザインの 一例である，ただし，このファサードは，鉄筋コンクリート構造を イメージし, 型枠が製作しや寸いよう, Step 123 の部材をある程度 統合し，力の流れを考慮したデザインとしている．また，図 18 は， 図 17 のファサードを用いた建物の外観イメージパースである.これ らの図より, 意匠設計者が, 提案手法で得られた位相をもとに, 建 物の構造デザインを行うことは十分可能であると考えられる. 

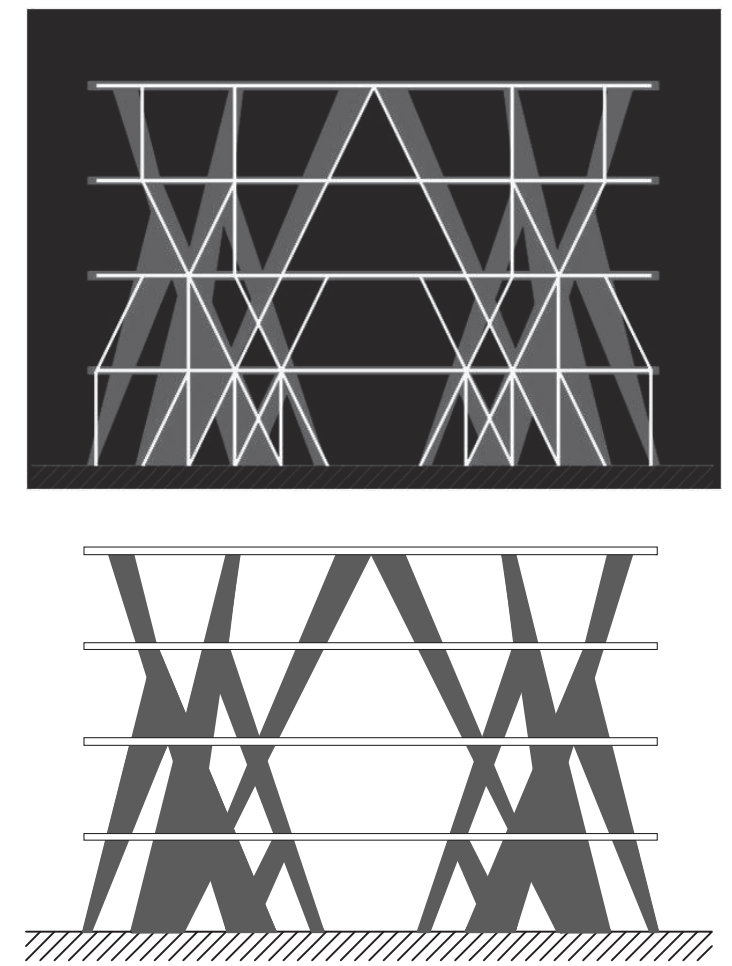

図 17 ファサードデザイン例

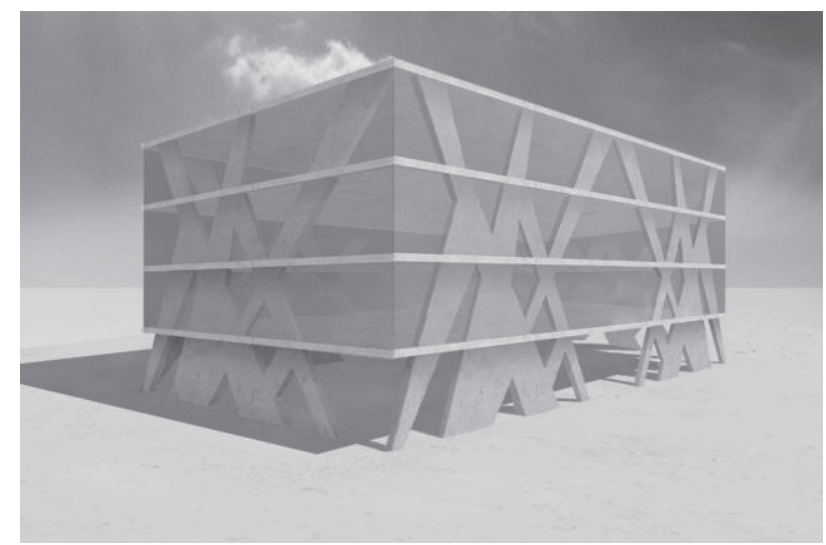

図 18 外観イメージパース

\section{5. まとめ}

本論文では, グランドストラクチャ法に初期の ESO 法（双方向で はなく一方向）の考え方を適用した骨組構造の簡易的な位相最適化 手法を提案した. そして, 提案手法により得られる解と従来の線要 素の材料密度を連続的に変化させて最適位相を求める方法（比較手 法）との解を比較し, 提案手法の有効性を検証した. その結果, 以 下のような知見が得られた。

(1) トラス構造の位相最適化問題では, 提案手法により, 比較手法 の最適解の位相と一致するかあるいは類似する位相が得られ, また, 類似する位相もコンプライアンスは大差なく, 最適解に 近い優良解となることがわかった.

(2) 剛接骨組構造の位相最適化問題でも, 比較手法において, 適当 な質量制約と解析パラメータを設定することで, 提案手法と一
致する最適位相が得られることがわかった。

(3) 建築物のファサードデザインを創生する問題では, 提案手法と 比較手法の解は類似性を持っているが, 完全に一致する位相は 得られなかった。 しかしながら, 提案手法では, 位相の変化が ステップごとに参照できるため, 力の流れを把握しやすく, こ れらをもとに, 力学的な合理性を有する構造デザインを考える

ことは十分可能であることがわかった。

以上の結果より, 本提案手法は, すべての場合に必ずしも最適解 を与えるものではないが, 構造設計や構造デザインに対して, 明確 な提案を与えることができ，また，計算アルゴリズムも非常に簡単 であることから, 動的問題や非線形問題など幅広い分野に応用が可 能であることがわかった。なお，本手法の最終解に到達するまでの 計算時間は解析例 4 においても通常のパソコンで数秒であり, 計算 負荷は小さいことを付記しておく.

今後は, 以上の方法を時刻歴応答問題に拡張し, 制震ブレースの 最適配置問題への適用を検討する予定である.

\section{参考文献}

1) Dorn, W., Gomory, R. and Greenberg, H. : Automatic design of optimal structures. J. de Mecanique, 3, 25-52, 1964

2) Rozvany, G.I.N. : Structural Design via optimality Criteria, Kluwer Academic Publishers, 1989.

3) Rozvany, G.I.N. (ed.) : Topology Optimization in Structural Mechanics, CISM Courses and Lectures 374, Springer, 1997

4) 河村拓昌, 大森博司：遺伝的アルゴリズムによる立体トラス構造物の形 態創生, 日本建築学会構造系論文集, 第 538 号, pp.115-121, 2000.12

5) 高田豊文, 松岡貴士 : 体積とコンプライアンスを目的関数としたトラス・ トポロジー最適化問題への線形計画法の適用, 日本建築学会構造系論文 集，第 598 号, pp.87-91，2005.12

6) 藤井大地, 松本慎也, 藤谷義信, 菊池昇 : グランドストラクチャー法に よる骨組構造物の位相最適化，構造工学論文集，Vol.46B，pp.1-8，2000.3

7) 藤井大地, 鈴木克幸, 大坪英臣 : 最適化手法 CONLIN を用いた骨組構造 の位相最適化, 日本建築学会構造系論文集, No.548, pp.59-66, 2001.10

8) 藤井大地, 真鍋匡利, 高田豊文 : グランドストラクチャ法による建築構 造の形態創生, 日本建築学会構造系論文集, 第 633 号, pp.1967-1973, 2008.11

9) 河村拓昌, 大森博司：遺伝的アルゴリズムによる接合状態を考慮した離 散的構造物の形態創生, 日本建築学会構造系論文集, 第 555 号, pp.121-128, 2002.5

10) Xie, Y. M., Steven, G. P. : A simple evolutionary procedure for structural optimization, Computers and Structures Vol.49, pp.885-886, 1993

11) Young, V., Querin, O. M., Steven, G. P. and Xie, Y. M. : 3D and Multiple Load Case Bi-Directional Evolutionary Structural Optimization (BESO), Structural Optimization, Vol.18, pp.183-192, 1999

12) Huang, X., Xie, Y. M. : Convergent and mesh-independent solutions for the bi-directional evolutionary structural optimization method, Finite Elements in Analysis and Design, Vol.43, pp.1039-1049, 2007

13) Steven, G. P., Querin, O. M., Xie, Y. M. : Evolutionary structural optimisation (ESO) for combined topology and size optimisation of discrete structures, Computer Methods in Applied Mechanics and Engineering, Vo.188, pp.743-754, 2000

14) Zhou, M., Rozvany, G.I.N. : On the validity of ESO type methods in topology optimization, Structural and Multidisciplinary Optimization, Vol.21, pp.80-83, 2001

15) 藤井大地：建築デザインと最適構造, 丸善, 2008 


\title{
TOPOLOGY OPTIMIZATION OF FRAME STRUCTURES USING ESO METHOD AND GROUND STRUCTURE METHOD
}

\author{
Kenji KOSAKA*, Shinya MATSUMOTO ${ }^{* *}$ and Daiji FUJII*** \\ * Grad. Stud., Graduate School of Systems Engineering, Kinki University \\ ** Assoc. Prof., Faculty of Engineering, Kinki University, Dr.Eng. \\ *** Prof., Faculty of Engineering, Kinki University, Dr.Eng.
}

In this paper, a simple method for topology optimization of frame structures is proposed. In this method, ESO (Evolutionary Structural Optimization) method is applied to ground structure method. An exact optimal solution may not be obtained by ESO method because it is a heuristic method. However, the approximate solution useful for structural design can be obtained by this method. In the proposed method, the ground structure is generated by connecting all nodes by beam elements (but it is possible to limit the length of the elements, and it is also possible to remove the unnecessary elements), and in the optimization process, the elements with the lowest strain energy are deleted based on ESO method.

The algorithm of the proposed method is as follows.

(1) The ground structure is analyzed by a static-elastic finite element analysis, and the strain energy density of all elements are calculated.

(2) The element number of survived elements are arranged in ascending order of strain energy density.

(3) The element with the most small strain energy density is eliminated. Also, if there are multiple elements which densities are equal to minimum one, these elements are eliminated all.

(4) The process from (1) to (3) is iterated until all the elements are eliminated. (See Fig.1)

(5) The solutions of all steps are displayed by visualization software (for example Micro AVS), and the user (designer) select an adapted one from these solutions.

In order to demonstrate the effectiveness of the present method, in several numerical examples, the solutions obtained by the proposed method are compared with the solutions obtained by the density approach (mathematical programming method). As a conclusion, the following knowledge were obtained.

(1) In the topology analysis of truss structure, almost solutions obtained by the proposed method were coincide with ones obtained by the density approach. Also, even if a different solution had been obtained, both solutions were similar. (Fig.2 Fig.10)

(2) In the topology analysis of frame structures with rigid connection, the matching solutions could be obtained, if the adaptive parameters (for example mass limit, penalty coefficient, etc.) were given for the density approach. (Fig.11 Fig.13)

(3) In the topology analysis of frame structure for facade design, the perfect matching solution could not be obtained. However, the solutions of both methods were similar. Therefore, the user (designer) can design the facade concept of buildings using the solutions obtained by the proposed method, because the solutions of each steps show that how receive the force each member. (Fig.14 Fig.18) 